\title{
Relationship between the conditions of lower airways in healthy horses, environmental factors and air quality in stables
}

\author{
Elisabetta Ferro', F. Ferrucci', Elisabetta Salimei'2, Micaela Antonin ${ }^{3}$, D. Codazza ${ }^{3}$ and M. Caniatti ${ }^{4}$ \\ 1 Istituto di Patologia Speciale e Clinica Medica Veterinaria, Facoltà di Medicina Veterinaria,Milano; \\ 2 Dip. SAVA, Facoltà di Agraria, Università del Molise; \\ ${ }^{3}$ Istituto di Malattie Infettive, Profilassi e Polizia Veterinaria, Facoltà di Medicina Veterinaria, Milano; \\ ${ }^{4}$ Istituto di Anatomia Patologica Veterinaria e Patologia Aviare, ibidem.
}

\begin{abstract}
Summary
In 6 healthy Haflinger horses stabled in individual boxes, different types of bedding (husk, straw and woodshavings) and hay (dry and soaked) were periodically changed.

After each test period (45 days) bronchoalveolar lavage (BAL) was carried out for each horse, and the BAL fluid (BALF) withdrawn was submitted for citological and microbiological evaluation. The environmental dust burden was evaluated by means of an air filtration system and an optical counter with laser diode. Dust particles were sorted in eight size classes ranging from 0.3 to $>20 \mu \mathrm{m}$. Qualitative evaluation of dust components was achieved by means of a Surface air system sampler (Sas).

Total dust, which ranged from $0.03 \mathrm{mg} / \mathrm{m}^{3}$ to $0.40 \mathrm{mg} / \mathrm{m}^{3}$, prooved highly related with mast cell differential count $(r=0.61 ; P=0.03)$. Besides, BALF mastcells differential count decreased significantly when hay was soaked. BALF alveolar macrophages showed a negative relationship with particles ranging from 1 to $2 \mu \mathrm{m}(r=-0.55 ; P=0.05)$ and from 2 to $5 \mu \mathrm{m}(r=-0.61 ; P=0.03)$, considered as respirable fraction (RF).

It was concluded that even in healthy horses the investigated factors may play an important role in lower airways condition.
\end{abstract}

Keywords: $\quad$ hay; bedding; total dust; respirable dust; bronchoalveolar lavage.

\begin{abstract}
Zusammenhang zwischen Stallhaltungsbedingungen und Lungenzustand bei gesundenen Pferden
Für sechs lungengesunde Haflinger Stuten wurden die Haltungsbedingungen im Stall abwechselnd verändert: Reisspreu (Häksel), Stroh und Holzspäne wurden als Boxeneinstreu verwendet und Heu entweder nass (feucht) oder trocken gefüttert. Am Anfang des Versuches standen die Tiere auf Reisspreu und erhielten trockenes Heu. Nach einer sorgfältigen klinischen Untersuchung wurde von jeder Stute mittels Spülsonde (BALF) Bronchialsekret gewonnen und zytologische sowie mikrobiologische Untersuchungen durchgeführt. Insgesamt änderte man 6 Mal nach jeweils 45 Tagen das Material der Boxeneinstreu oder die Fütterungart von Heu. Am Ende eines jeden Zeitraumes wurden die beschriebenen Untersuchungen durchgeführt. Zum gleichen Zeitpunkt wurden mittels eines Lufffiltergeräts und eines Laserabnahmesystems Gesamt- und Atemluftstaub mit gemessen. Die Staubpartikel sind aufgrund ihrer Durchmesser (von 0.3 bis mehr als 20 micr.), in acht Gruppen eingeteilt worden und die Bestandteile des Staubs wurden mit einem "Surface air system" (Sas) gesammelt und identifiziert. Die Ergebnisse zeigen, dass die Staubdichte im Pferdestall in Beziehung zur Anzahl der Mastzellen in BALF ( $r=0.61 ; P=0.03$ ) steht. Die Menge dieser Zellen war deutlich vermindert wenn den Stuten feuchtes Heu gefüttert worden war. Eine negative Korrelation bestand zwischen der Zahl alveolärer Makrophagen und der Staubdichte der Größe 1 bis 2 micr. und 2 bis 5 micr.
\end{abstract}

Schlüsselwörter: Heu, Einstreu, Gesamtstaub (Totalstaub), Atemluftstaub, Bronchialsekretproben (BALF)

\section{Introduction}

Environmental hygiene is currently acknowledged as an important factor involved in the pathogenesis of several respiratory disorders of the horse, such as chronic obstructive pulmonary disease (COPD) and inflammatory airway disease (IAD) (Clarke, 1987a; Woods et al., 1993; Moore, 1996).

Antigens found in bedding and fodder (fungal spores, mycetes, pollens, etc.) are able to induce bronchospasm and/or an inflammatory response of the airways, as demonstrated by specific tests (skin test, in vitro test, inhalatory challenge test, etc.) (Mc Pherson et al., 1979; McGorum et al., 1993). Therefore, the control of environmental conditions represents a main point for preventing the occurrence of respiratory disorders as well as an essential part of the therapeutic approach to affected animals.

Moreover, for the assessment of animal welfare, a considerable importance has been attributed to airborne particles' size, particularly of the respirable fraction (RF) which ranges between 0.3 and 5.0 um (Carpenter, 1986).

The aim of the present study was to evaluate qualitative and quantitative variations of environmental dust related to different types of bedding and feeding management and their influence on the microbiological and cellular components of bron- 
choalveolar lavage fluid (BALF) from healthy horses, which is considered as a reliable indicator of lower airway conditions (Mair et al., 1987; Derksen et al., 1989).

\section{Materials and methods}

In the present study 6 pluripares Haflinger mares, 6 to 14 years old, were used. The mares were considered healthy according to the results of both physical examination, serology and laboratory evaluation. Mares were stabled in recently built individual boxes, separated by concrete walls which did not reach the roof, leaving an open space of 1 metre between boxes. Each box was provided with an external covered grooming passage and a "vasistas"-like window, located on the rear wall, which was always kept open in order to ensure adequate natural ventilation. Throughout the study, the boxes were cleaned twice daily, keeping the horses outside during the procedure.

Each mare received in average $8.5 \mathrm{~kg}$ of mixed hay (CP 10\% d.m.) and $3.5 \mathrm{~kg}$ of pelleted horse feed (CP 18\% d.m.) per day. The animals were fed twice daily, at 8.00 am and $5.00 \mathrm{pm}$.

The mares were vaccinated and dewormed on a regular basis. In order to evaluate the effect of different management systems on the conditions of lower airways in healthy horses, periodical variations of environmental conditions, concerning the type of bedding (husk, straw or woodshavings) and hay (dry or soaked by dipping in water for a few hours), were carried out. "Husk", which represents a popular bedding material in Northern Italy, due to the presence of intensive rice cropping, consists of the external envelope of rice seeds as a byproduct of milling industry. The whole study lasted 270 days (January-June and SeptemberNovember), divided into 6 different experimental periods of 45 days.

At the beginning of each period, a single environmental parameter (either hay or bedding) was changed, as summarised in table 1, and on $45^{\text {th }}$ day a physical examination, laboratory evaluation (haematology, serum biochemistry and faecal egg count) and bronchoalveolar lavage (BAL) were performed for each horse. At the same time, the collection of samples for the air quality evaluation was carried out by means of three different techniques. Both environmental temperature and relative humidity were also monitored.

\section{Bronchoalveolar lavage technique}

The technique for performing $\mathrm{BAL}$ in the horse has been described elsewere (Fogarty, 1990; Ferrucci et al., 1995). Briefly, the left nostril was carefully cleaned with $70^{\circ}$ alcohol and a $70 \mathrm{~cm}$ long, sterile, polypropilene tube, tube $A^{\prime}$, was introduced into the ventral meatus until it reached the proximal third of the trachea. A second $240 \mathrm{~cm}$ long sterile tube (tube B) was introduced into tube $A$ until it was wedged in a bronchus. Two $60 \mathrm{ml}$ each boluses of sterile saline were then injected into tube $B$ and immediately aspirated. The fluid withdrawn was collected into two sterile plastic containers - in order to avoid adherence of alveolar macrophages to the walls of the container - and stored at $4{ }^{\circ} \mathrm{C}$ until submission to the laboratory.

\footnotetext{
1 Fogarty lungwash tubes, Cerdix Ltd, England
}

\section{Citology}

After a macroscopic evaluation of BALF, $5 \mathrm{ml}$ were centrifuged at $1000 \mathrm{rpm}$ for 15 minutes. $1 \mathrm{ml}$ of surnatant was used to resuspend the cell pellet. Then, $0.25 \mathrm{ml}$ of resuspended fluid were cytocentrifuged (Shandon cytofuge) at 500 rpm for 5 minutes. Slides were air dried, stained with May Grünwald-Giemsa and observed at 400x for the differential count. The cellularity, the amount of mucus and the presence of fagocitized material in the cytoplasm of macrophages and neutrophils were registered. Alveolar macrophages, lymphocytes, neutrophils, eosinophils and mastcells were considered for the differential count. The presence of ciliated and non ciliated epithelial cells, pharyngeal squamous cells and red blood cells was also registered, but not included in the differential count.

Tab. 1: Environmental conditions during the six experimental periods Haltungsbedingungen während der sechs Zeitabschnitte des Versuches

\begin{tabular}{|c|c|c|}
\hline $\begin{array}{c}\text { 45 days } \\
\text { period }\end{array}$ & $\begin{array}{c}\text { Environmental } \\
\text { conditions }\end{array}$ & Controls \\
\hline PERIOD 1 & $\begin{array}{c}\text { husk bedding }+ \\
\text { dry hay }\end{array}$ & $\begin{array}{c}\text { BAL + evaluation of } \\
\text { environmental dust }\end{array}$ \\
\hline PERIOD 2 & $\begin{array}{c}\text { husk bedding }+ \\
\text { soaked hay }\end{array}$ & $\begin{array}{c}\text { BAL + evaluation of } \\
\text { environmental dust }\end{array}$ \\
\hline PERIOD 3 & $\begin{array}{c}\text { straw bedding }+ \\
\text { soaked hay }\end{array}$ & $\begin{array}{c}\text { BAL + evaluation of } \\
\text { environmental dust }\end{array}$ \\
\hline PERIOD 4 & $\begin{array}{c}\text { straw bedding }+ \\
\text { dry hay }\end{array}$ & $\begin{array}{c}\text { BAL + evaluation of } \\
\text { environmental dust }\end{array}$ \\
\hline PERIOD 5 & $\begin{array}{c}\text { woodshavings bedding } \\
+ \text { dry hay }\end{array}$ & $\begin{array}{c}\text { BAL + evaluation of } \\
\text { environmental dust }\end{array}$ \\
\hline PERIOD 6 & $\begin{array}{c}\text { woodshavings bedding } \\
+ \text { soaked hay }\end{array}$ & $\begin{array}{c}\text { BAL + evaluation of } \\
\text { environmental dust }\end{array}$ \\
\hline
\end{tabular}

Bacteriology

$10 \mathrm{ml}$ of lavage fluid were centrifuged at $4000 \mathrm{rpm}$ for $15 \mathrm{mi}$ nutes. The pellet was inoculated into blood agar with a $2 \mu \mathrm{l}$ calibrated loop and incubated at $37^{\circ} \mathrm{C}$ under aerobic and anaerobic conditions. In case of growth, bacterial colonies were identified and counted.

Mycology

Part of the pellet obtained by centrifugation for bacteriology was inoculated into Sabouraud maltose and incubated at $30^{\circ} \mathrm{C}$ and $37^{\circ} \mathrm{C}$ for 10 days. In case of growth, mycetes colonies were identified and counted.

\section{Evaluation of environmental dust burden}

\section{Light scattering system}

Environmental dust concentration was quantified according to particles size by the means of a light scattering system (HyacRoyco mod.5230) that collect dust in real time. Measurements were carried out inside the boxes by placing the aspiration device at $150 \mathrm{~cm}$ from the ground. 
The dimensional evaluation of airborne particle concentration (particles $\left./ \mathrm{m}^{3}\right)$ was achieved by setting 8 size classes $\left(\mathrm{C}_{1}: 0.3-0.5\right.$ $\mu \mathrm{m} ; \mathrm{C}_{2}: 0.5-1.0 \mu \mathrm{m} ; \mathrm{C}_{3}: 1.0-2.0 \mu \mathrm{m} ; \mathrm{C}_{4}: 2.0-5.0 \mu \mathrm{m}$; $C_{5}: 5.0-10.0 \mu \mathrm{m} ; C_{6}: 10.0-15.0 \mu \mathrm{m} ; C_{7}: 15.0-20.0 \mu \mathrm{m} ;$ $\left.\mathrm{C}_{8}:>20 \mu \mathrm{m}\right)$. During the study the size classes were reduced to 7 (from $C_{1}$ to $C_{7}$ ) by grouping all of the particles $>15 \mu \mathrm{m}$ into class $C_{7}$ as the count of particles ranging from $15 \mu \mathrm{m}$ to $>20$ um was negligible.

Besides the particles count for each class, both the respirable fraction (RF, particles $/ \mathrm{m}^{3}$ ), i.e. the sum of particles ranging in diameter from 0.3 to $5.0 \mu \mathrm{m}$, and total dust (TD, particles $/ \mathrm{m}^{3}$ ), i.e. the sum of all particle classes, were evaluated.

\section{Air filtration system}

For the quantitative evaluation of environmental dust, expressed as total mass $/ \mathrm{m}^{3}$, six equal sampling stations were used. Each station consists of a pump with a counterpoised piston and constant, pre-set flow (10 l/min). Three open face membrane holders were attached to three of these pumps to determine total dust (TD mg/m $\mathrm{m}^{3}$ ). Three two-stage cyclones (Lippmann selector, as recommended by the $\mathrm{ACGIH}, 1987)$ were used to measure the respirable fraction $\left(\mathrm{RF}, \mathrm{mg} / \mathrm{m}^{3}\right)$. Nitrocellulose membranes with $20 \mathrm{~mm}$ diameter, $0.8 \mu \mathrm{m}$ pore size and $14 \mathrm{~mm}$ dust spot, were weighed using a microbalance before and after dust collection in a controlled humidity room.

\section{Surface air system (SAS)2}

Qualitative evaluation of environmental dust was achieved by means of a surface air system, which allows the aspiration of environmental air and the collection of dust on either blood agar plates, to culture airborne bacteria, or saboureaud plates, to culture airborne mycetes. Both samples were collected at 60, 90 and 120 air litres/min.

All blood agar plates and those saboureaud plates collected at 60 air litres/min were incubated at $37^{\circ} \mathrm{C}$ for 24 hours, while the remaining saboureaud plates (90 and 120 air litres/min) were incubated at $30^{\circ} \mathrm{C}$ for 72 hours. Bacterial species, fungal genera and yeast which grew on the plates were then identified.

\section{Microbiological evaluation of hay and bedding}

Samples of hay and bedding, collected at the end of each period directly from the boxes, were processed according to Cantoni and Dragoni (1987).

\section{Statistical analysis}

Mycetes from SAS samples were qualitatively analyzed by the exact Fisher's test (SAS/STAT software).

The variations of environmental dust concentration, alveolar cell populations, and log converted data on bacterial species, fungal genera and yeast were statistically analyzed by the GLM procedure of SAS/STAT software (1988), with two main factors (hay and bedding), considering also the secondary effect of the animals due to individual variations and the co-variate effects of environmental temperature and relative humidity. A two tails $f$-test was used to determine the levels of significance of the correlation between the considered parameters.

\section{Results}

Throughout the study, the mares did not show any sign of respiratory disease and the results of the physical examination and laboratory evaluation performed at the end of each experimental period fell into normal ranges.

\section{Environmental Temperature (T) and Relative Humidity (RH)}

Figure 1 shows the variations of $\mathrm{T}\left({ }^{\circ} \mathrm{C}\right)$ and $\mathrm{RH}(\%)$ registered inside the boxes during the collection of dust samples. $\mathrm{RH}$ did not vary significantly during the different experimental periods.

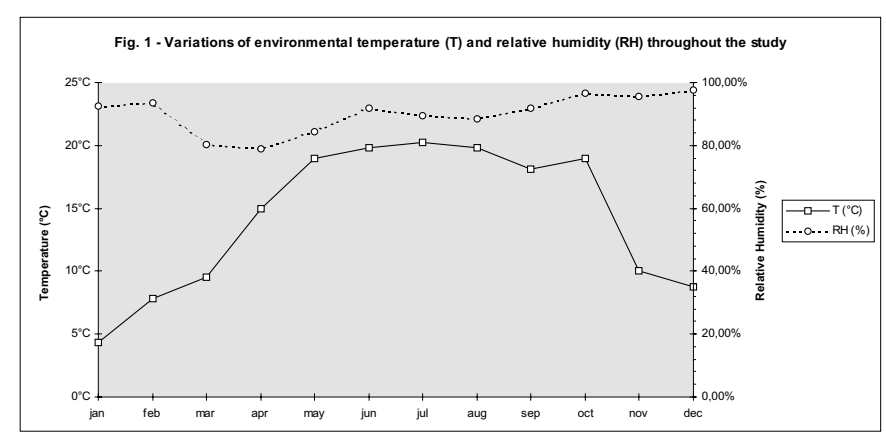

Fig. 1: Variations of environmental temperature (T) and relative humidity (RH) throughout the study

Veränderungen der Wärmelage (Schwankungen der Temperaturbedingungen) (T) und der Feuchtigkeit (relativa) im Verlauf des Versuches

\section{Alveolar Cell Populations}

Table 2 shows the differential count for alveolar cell populations from BALF (lymphocytes, alveolar macrophages, neutrophils, eosinophils and mastcells) according to variations of environmental conditions during the different experimental periods. Statistical analysis shows significant effects of bedding on all the alveolar cell populations except for neutrophils. Mastcells were significantly affected by hay and bedding $(P<0.01)$ and their interaction $(\mathrm{P}<0.05)$.

Focusing only on bedding management, the lymphocytes differential count resulted in average elevated $(40.6 \%)$ when woodshavings were used, while the opposite was detected (14.5\%) when straw bedding was used. On the other hand, the alveolar macrophages differential count was higher in average (74.1\%) when straw bedding was used and lower values were observed (45.9\%) when woodshavings bedding was used.

The eosinophils differential count, although always very low, was higher (1.6\%) when husk bedding was used, it was almost negligible when the other two types of bedding were used, particularly when hay was soaked.

The highest average differential count for mastcells (8.75\%) was observed when husk bedding was used, although the soaking of hay lowered this parameter significantly (3.8\% vs. 13.7\%). Similarly, mastcells differential count was lower when straw bedding

${ }^{2}$ SAS compact, $P B I$ International 
was used (average 1.65\%) and it was lowered further by the soaking of hay $(0.1 \%$ vs $3.2 \%)$.

Finally, as far as neutrophils differential count is concerned, this was highest (13.6\%) when straw bedding was used, while the lowest count (3.8\%) was observed with woodshavings bedding, although these variations were not statistically significant.
No significant influence of the considered factors was observed for larger particles, whose concentration was however very low at any period (table 3).

The highest values for both TD and RF concentration were registered when woodshavings bedding and dry hay were used (period 5). It has to be noted the dramatic decrease in both TD and RF when soaked hay was fed (period 6) while when straw

Tab. 2: Mean percentage values of alveolar cell popularion ( \pm s.e.m.)

(Durchschnittlicher) Mittlerer Prozentsatz von alveolaeren Mastzellen ( \pm std)

\begin{tabular}{|l|c|c|c|c|c|c|c|c|c|}
\hline \multicolumn{7}{|c|}{ Environmental conditions } & \multicolumn{4}{c|}{ P } \\
\hline $\begin{array}{l}\text { Alveolar cell } \\
\text { populations }\end{array}$ & 1 & 2 & 3 & 4 & 5 & 6 & hay & bed & h*b \\
\hline Lymphocytes, \% & $14.1 \pm 6.4$ & $19.2 \pm 6.4$ & $12.2 \pm 5.6$ & $16.9 \pm 6.4$ & $41.3 \pm 5.6$ & $40.0 \pm 5.0$ & $\mathrm{~ns}$ & $* * *$ & $\mathrm{~ns}$ \\
\hline Macrophages, \% & $63.5 \pm 7.0$ & $72.5 \pm 7.1$ & $73.7 \pm 6.2$ & $74.5 \pm 7.1$ & $44.3 \pm 6.2$ & $47.5 \pm 5.5$ & $\mathrm{~ns}$ & $* * *$ & $\mathrm{~ns}$ \\
\hline Eosinophils, \% & $3.3 \pm 1.0$ & $0 \pm 1.0$ & $0 \pm 0.8$ & $0 \pm 1.0$ & $1.6 \pm 0.9$ & $0.3 \pm 0.8$ & $\mathrm{~ns}$ & $*$ & $\mathrm{~ns}$ \\
\hline Mast cells, \% & $13.7 \pm 1.6$ & $3.8 \pm 1.6$ & $0.1 \pm 1.4$ & $3.2 \pm 1.6$ & $5.6 \pm 1.4$ & $5.8 \pm 1.2$ & $* *$ & $* *$ & $*$ \\
\hline Neutrophils, \% & $5.8 \pm 3.3$ & $4.9 \pm 3.3$ & $13.6 \pm 2.9$ & $6.0 \pm 3.3$ & $7.4 \pm 2.9$ & $3.8 \pm 2.6$ & $\mathrm{~ns}$ & $\mathrm{~ns}$ & $\mathrm{~ns}$ \\
\hline
\end{tabular}

Environmental conditions: $\quad 1$ = dry hay, husk bedding; 2 = soaked hay, husk bedding 4 = dry hay, straw bedding; 5 = dry hay, woodshavings bedding; Effects $(\mathrm{P})$ : hay= soaked vs. dry; bedd.= bedding; $\quad \mathrm{h}^{*} \mathrm{~b}=$ hay hed $^{2}$ beding interaction. 3 = soaked hay, straw bedding; 6 = soaked hay, woodshavings bedding. $\mathrm{P}=\mathrm{ns}$ : not significant;

$$
\text { ***: } \mathrm{P}<0.001 ; \quad \text { **: } \mathrm{P}<0.01 ; \quad \text { *: } \mathrm{P}<0.05 \text {. }
$$

Environmental dust and its relationship with alveolar cell populations

From a quantitative point of view, total dust (TD) ranged between $0.03 \mathrm{mg} / \mathrm{m}^{3}$ and $0.40 \mathrm{mg} / \mathrm{m}^{3}$, while the respirable fraction (RF) ranged between $0.019 \mathrm{mg} / \mathrm{m}^{3}$ and $0.30 \mathrm{mg} / \mathrm{m}^{3}$.

Further investigation on airborne particles according to their size allowed the possibility to obtain the mean values for TD and RF, given as particles $/ \mathrm{m}^{3}$, and the granulometric composition of dust considered as the percentage value of TD for each particles class (table 3).

Throughout the study, TD concentration remained approximatively at a level of $10^{8}$ particles $/ \mathrm{m}^{3}$, and was composed for more than $94 \%$ by RF.

The statistical analysis showed (table 3 ) that the considered environmental factors - the soaking of hay and the type of bedding used - have a significant influence on environmental dust concentration (TD and RF); besides, no associative effects of the same factors were observed on both TD and RF. The administration of either dry or soaked hay had a significant influence on concentration of particles ranging between $0.3 \mu \mathrm{m}$ and $2.0 \mu \mathrm{m}$, while the type of bedding used had a significant influence on airborne particles sizing up to $5.0 \mu \mathrm{m}$. bedding and soaked hay were used the lowest values were registered (period 3), as table 3 shows.

The analysis of the particle size composition of dust, expressed as $\%$ of TD, showed that the highest count $(91.02 \%)$ for $C_{1}$ particles $(0.3-0.5 \mu \mathrm{m})$ was registered in period 4 (straw bedding and dry hay); while the opposite was true (82.1\%) for period 5 (woodshavings bedding and dry hay). However, in period 5, the highest count (16.08\%) for $C_{2}$ particles $(0.5-1.0 \mu \mathrm{m})$ was registered. The latter count fell to $1.13 \%$ in the next period (period $6)$, when hay was soaked. As far as particles ranging from 1.0 $\mu \mathrm{m}$ to $2.0 \mu \mathrm{m}$ are concerned, the highest count (1.56\%) was registered in period 5 and the lowest count $(0.53 \%)$ was registered in periods 3 and 4 when straw bedding was used, where the soaking of hay did not significantly affect concentration of particles class $C_{3}$. The highest count $(0.44 \%)$ for particles $C_{4}$ class was registered in period 4 (straw bedding and dry hay) while the opposite was true $(0.18 \%$ ) in period 1 (husk bedding and dry hay). As far as the relationship between alveolar cell populations and environmental dust concentration is concerned, alveolar macrophages differential count showed a negative correlation with particles ranging from $0.5 \mu \mathrm{m}$ to $2.0 \mu \mathrm{m}(r=-0.55 ; \mathrm{P}=0.05)$ and from 2.0 to $5.0 \mu \mathrm{m}(r=-0.61 ; P=0.03)$.

Conversely, mastcells differential count showed a positive correlation with particles ranging from $0.3 \mu \mathrm{m}$ to $0.5 \mu \mathrm{m}(r=$ 
$0.65 ; P=0.02)$ and with particles ranging from $5.0 \mu \mathrm{m}$ to $15.0 \mu \mathrm{m}(r=0.62 ; P=0.02)$.

Mycetes and Bacteria

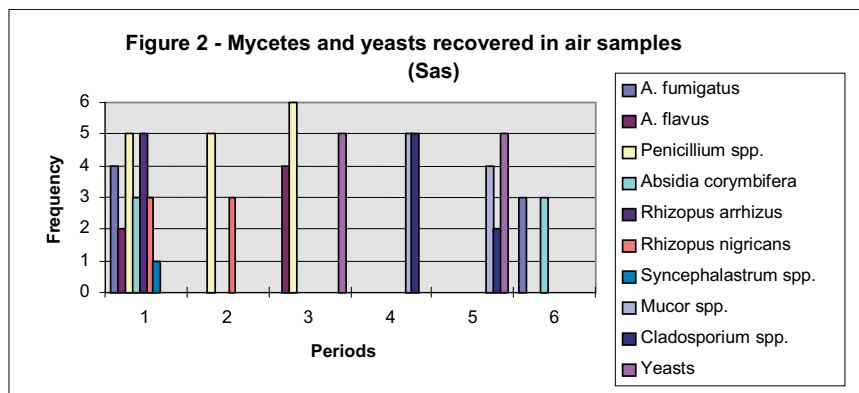

Fig. 2: Mycetes and yeasts recovered in air samples

Mycetes und Hefen in der Stallluft (Sas)

Only those bacteria and mycetes which were significantly affected by the investigated parameters will be presented.

Aspergillus flavus and A. glaucus counts were affected by bedding as well as yeasts count. The effect of hay was found significant on A. flavus, yeasts and Mucor spp. counts. Mycetes frequency observed in Sas samples is shown in Fig. 2.

The number of fungal spores from BALF (Fig.3) was always lower than that from environmental air, and it was higher (12\%) when straw bedding and dry hay were used. When husk bedding and soaked hay were used (period 2), the lowest number of fungal spores from BALF was registered (3\%).

The number of fungal spores from environmental air was higher (39\%) when husk bedding and dry hay were used (period 1), while it was lower (11\%) when woodshavings and soaked hay were used (period 6). Among different fungal genera, Aspergillus spp. was the most frequently observed, both in BALF and Sas samples, while Penicillium spp. was also frequent in Sas samples. Their size is always comprised between $2 \mu \mathrm{m}$ and 4 $\mu \mathrm{m}$ and therefore they belong to RF. Similarly, yeasts concentration increased both in BALF (Fig. 3) and Sas samples (Fig. 2) when straw bedding was used.

Fig. 4 shows bacterial species isolated from both BALF and Sas samples: as for mycetes, the environmental bacterial burden was more elevated than that from BALF. Bacterial number was elevated (20 and 22\%) when husk and straw bedding was used. In the same periods (1 and 3) the bacterial number from BALF was also high although among the different bacterial species no pathogens were identified.

\section{Discussion}

The high level of environmental dust registered inside the boxes, both for TD and RF given as $\mathrm{mg} / \mathrm{m}^{3}$, substantially agrees with that observed by other authors (Woods et al., 1993; Navarotto et al., 1994).

Regarding this, TD was always lower than that observed by Woods et al. (1993) under "conventional" management sy-

Tab. 3: Mean composition of environmental dust ( \pm s.e.m.)

Durchschnittliche Zusammensetzung des Gesamtstaubes

\begin{tabular}{|c|c|c|c|c|c|c|c|c|c|}
\hline \multicolumn{7}{|c|}{ Environmental conditions } & \multicolumn{3}{|c|}{$\mathbf{P}$} \\
\hline & 1 & 2 & 3 & 4 & 5 & 6 & hay & bed & $h * b$ \\
\hline TD, part./m³ & $\begin{array}{c}7.71 \times 10^{8} \\
\pm \quad 1.15 \times 10^{7}\end{array}$ & $\begin{array}{l}3.80 \times 10^{8} \\
\pm \quad 1.03 \times 10^{7}\end{array}$ & $\begin{array}{c}1.33 \times 10^{8} \\
\pm 1.30 \times 10^{7}\end{array}$ & $\begin{array}{l}2.68 \times 10^{8} \\
\pm 1.03 \times 10^{7}\end{array}$ & $\begin{array}{r}10.28 \times 10^{8} \\
\pm \quad 1.12 \times 10^{7}\end{array}$ & $\begin{array}{l}2.76 \times 10^{8} \\
\pm \quad 1.16 \times 10^{7}\end{array}$ & $* * *$ & $* * *$ & $* * *$ \\
\hline $\mathrm{RF}$, part. $/ \mathrm{m}^{3}$ & $\begin{array}{c}7.71 \times 10^{8} \\
\pm \quad 2.97 \times 10^{7}\end{array}$ & $\begin{array}{c}3.77 \times 10^{8} \\
\pm \quad 2.65 \times 10^{7}\end{array}$ & $\begin{array}{c}1.30 \times 10^{8} \\
\pm \quad 3.34 \times 10^{7}\end{array}$ & $\begin{array}{c}2.67 \times 10^{8} \\
\pm \quad 2.64 \times 10^{7}\end{array}$ & $\begin{array}{c}9.63 \times 10^{8} \\
\pm \quad 2.88 \times 10^{7}\end{array}$ & $\begin{array}{c}2.76 \times 10^{8} \\
\pm \quad 2.97 \times 10^{7}\end{array}$ & $* * *$ & $* * *$ & $* * *$ \\
\hline \multicolumn{10}{|l|}{$\begin{array}{l}\text { Percentage of } \\
\text { TD: }\end{array}$} \\
\hline$C_{1}: 0.3-0.5 \mu \mathrm{m}$ & 88.83 & 90.11 & 90.73 & 91.02 & 82.08 & 87.50 & $* * *$ & $* * *$ & $* * *$ \\
\hline$C_{2}: 0.5-1 \mu \mathrm{m}$ & 10.25 & 8.74 & 8.51 & 7.88 & 16.08 & 1.13 & $* * *$ & $* * *$ & $* * *$ \\
\hline$C_{3}: 1-2 \mu \mathrm{m}$ & 0.73 & 0.71 & 0.53 & 0.53 & 1.56 & 0.89 & $* * *$ & $* * *$ & $* * *$ \\
\hline$C_{4}: 2-5 \mu \mathrm{m}$ & 0.18 & 0.40 & 0.19 & 0.44 & 0.27 & 0.26 & ns & $* * *$ & $* * *$ \\
\hline$C_{5}: 5-10 \mu \mathrm{m}$ & 0.016 & 0.041 & 0.032 & 0.112 & 0.003 & 0.009 & ns & ns & ns \\
\hline$C_{6}: 10-15 \mu \mathrm{m}$ & 0.002 & 0.003 & 0.006 & 0.015 & 0.004 & 0.001 & ns & ns & ns \\
\hline$C_{7}:>15 \mu \mathrm{m}$ & 0 & 0.002 & 0.002 & 0.004 & 0 & 0 & ns & ns & ns \\
\hline
\end{tabular}

Legend see table 1 
stems; moreover, in each experimental period, RF fell into the range required to ensure horse welfare, as reported by Zeitler Feicht (1993). This supports the hypothesis postulated by Robinson (1992) concerning the multifactoriality of problems related to environmental dust in stables. Particularly, both the structural typology of buildings and the environmental hygiene conditions could significantly affect air quality.

RF particles count also fell into the wide range reported for the horse by Pickrell (1991). The use of modern techniques for envi-

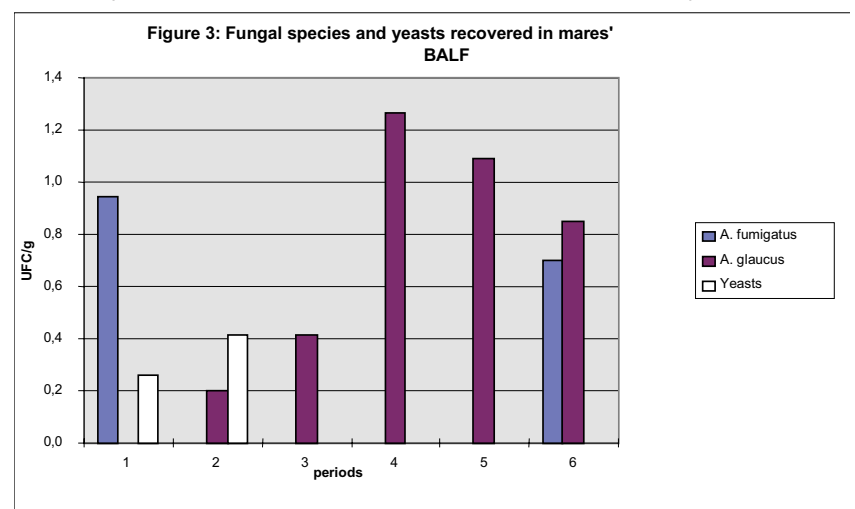

Fig. 3: Fungal species and yeasts recovered in mares

Mycetes und Hefen in BALF

ronmental dust measurement showed that the considered management factors significantly affect both environmental TD and RF. The statistical model used reliably explains the variability of results, although the contribution due to seasonal effects cannot be ruled out; however, RH did not vary significantly throughout the study.

Since TD is made up for more than $94 \%$ of respirable particles, it can be hypothesized that the observed variations of the al-

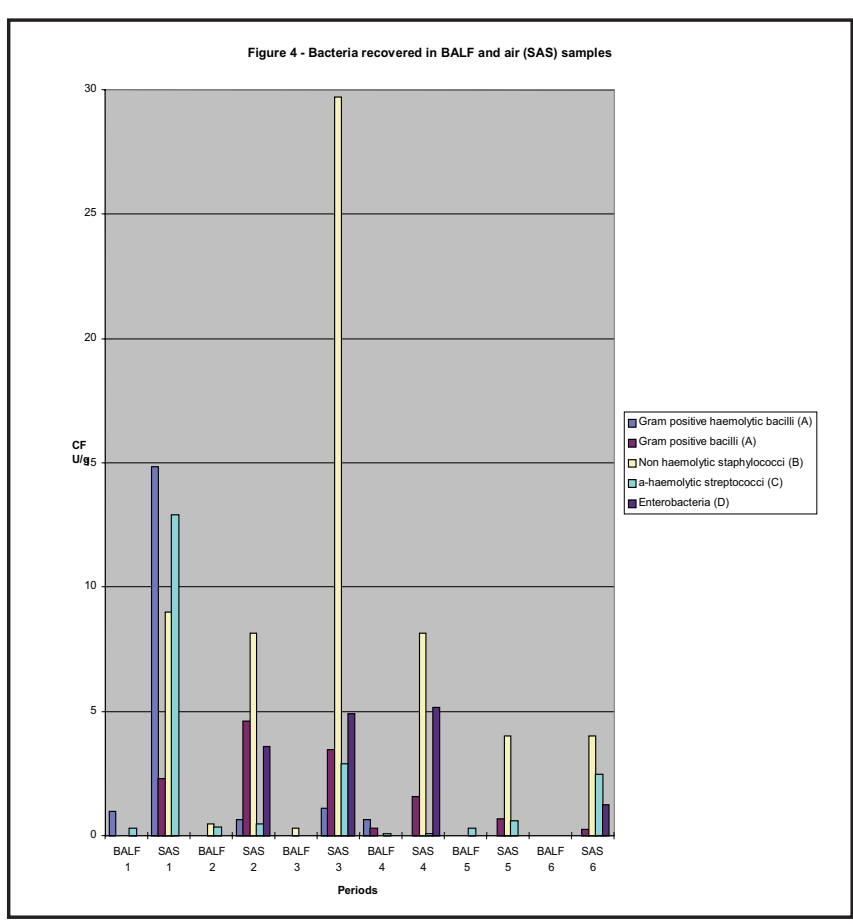

Fig. 4: Bacteria recovered in BALF and air (SAS) samples

Bakterien in BALF und in der Stallluft (SAS) veolar cell population differential count are due to the inhalation of particles ranging from $0.3 \mu \mathrm{m}$ to $5.0 \mu \mathrm{m}$.

As far as mastcells differential count is concerned, significant variations $(P<0.05)$ were registered following modification of environmental conditions, and a direct significant relationship with TD and RF concentration was also observed. Respiratory mastcells, which are found mainly in bronchoalveolar spaces (Mair et al., 1988), have been universally acknowledged as playing an important role in the bronchial response to inhaled antigens. They do not only release the chemical mediators for allergic response (hystamine, arachidonic acid and its metabolites, leukotrienes, etc.) but are also involved in the development of the immune response and of its cytotoxic effects (Mair et al., 1988). Since Aspergillus spp. and Penicillium spp. spores, belonging to the RF, were the most frequently observed in BALF and SAS samples, it is likely that environmental dust, and particularly those fungal spores, is responsible for mastocitic proliferation.

Alveolar macrophages and lymphocites differential count was statistically influenced by the type of bedding only. Particularly, a significant increase of lymphocites differential count $(P<$ 0.001 ) was observed at the end of periods 5 and 6 , when the animals were bedded on woodshavings. In the same periods, a significant decrease $(P<0.001)$ in alveolar macrophages differential count was also observed. (However, it has to be stressed that the observed variations refer to percentage values and not to absolute values and therefore the increase in lymphocites differential count may actually be due to a decrease in macrophages differential count.) This finding could be related to the slight decrease of RF, particularly of those particles ranging from $0.3 \mu \mathrm{m}$ to $0.5 \mu \mathrm{m}$, registered when woodshavings bedding was used.

Neutrophils differential count was not significantly affected by the different environmental conditions throughout the study, although it was more elevated when straw bedding was used. However, neutrophils differential count variation should not be expected from healthy horses, since they vary significantly only in COPD affected horses when bedded on straw and fed poor quality hay (Derksen et al., 1985).

No pathogenic bacteria were detected in environmental air, nevertheless it should be considered that since their size always falls in the respirable range, they could still represent a proinflammatory challenge for stabled horses.

The results obtained suggest that the type of bedding and hay may have a twofold influence both on air quality inside the boxes and on variations of alveolar cell populations in healthy horses, particularly as far as mastcells are concerned.

This study highlights the complexity of problems related to environmental dust, considered as an important component of air quality, implicated in the genesis of several respiratory disorders of the horse, as demonstrated by the relationship observed between BALF citological composition and the finest fraction of dust, i.e., the respirable fraction.

From a practical point of view, the soaking of hay had positive effects on both air quality and mastcells differential count. As far as the type of bedding used is concerned, husk represents an undesirable bedding substrate since it induced an increase in both environmental dust concentration and the mastcells and 
eosinophils differential count; therefore, it could possibly promote the occurence of respiratory inflammation in predisposed animals; woodshavings could be a better substrate, since a decrease in both percentage value of $C_{1}$ particles fraction (the most hazardous fraction) and alveolar macrophages differential count was observed when they were used. Since alveolar macrophages are involved both in the early stages of the immune response to allergens and in the phagocytosis of foreign material, such as fungal spores (Sibille and Reynolds, 1990), their differential count decrease could represent a desirable feature in the prevention of inflammatory respiratory disorders in predisposed animals. Moreover, the lowest value for airborne fungal spores was observed with woodshavings, and this observation seems to support their possible involvement in determining variations of certain cell populations.

Good quality straw may represent a satisfactory bedding substrate for healthy horses, as the observed decrease in both environmental dust concentration and mastcells differential count suggests. However, yeasts contamination of bedding as well as the slightly higher macrophages and neutrophils differential count detected suggest that straw bedding could represent an undesirable feature for horses predisposed to respiratory problems.

\section{Acknowledgements}

The Authors wish to acknowledge Prof. V. Dell'Orto and "Villa Segù" Therapeutic Community for the kind co-operation and M. Guarino for her technical assistance. Special thanks to Prof. E. Deegen and B. Ohnesorge for reviewing the manuscript.

\section{References}

American Conference of Governmental Industrial Hygienists (1987): Treshold limit values and biological exposure indices for 1986-1987. Cincinnati, OH: A.C.G.I.H.

Cantoni C. and I. Dragoni (1987): Muffe e alimenti. Ed: Clesav, Milan (Italy)

Carpenter G.A. (1986): Dust in livestock buildings: review of some aspects. J. of Agric. Eng. Res. 33: 227-241

Crichlow E.C., K. Yoshida and K. Wallace (1980): Dust levels in a riding stable. Equine Vet J. 12: 185-188

Clarke A.F. (1987): A review of environmental and host factors in relation to equine respiratory disease. Equine Vet. J. 19, 435-441.

Derksen F.J., J.S. Scott, D.C. Miller, R.F. Slocombe and N.E. Robinson (1985): Bronchoalveolar lavage in ponies with recurrent airway obstruction (heaves). Am. Rev. Respir. Dis. 132, 1066-1070.

Derksen F.J., C.M. Brown, I. Sonea, B.J. Darien and N.E. Robinson (1989): Comparison of transtracheal aspirate and bronchoalveolar lavage cytology in 50 horses with chronic lung disease. Equine Vet. J. $21,23-26$.

Ferrucci F., E. Ferro, D. Codazza and I. Dragoni (1995): The use of bronchoalveolar lavage for the evaluation of respiratory conditions in the equine athlete. Proceedings of the 1995 AESM Meeting. Fallbrook, California, 16-20.

Fogarty U. (1990): Evaluation of a bronchoalveolar lavage technique. Equine Vet. J. 22, 174-176.

Mair T.S., C.R. Stokes and F.J. Bourne (1987): Cellular content of secretions obtained by lavage from different levels of the equine respiratory tract. Equine Vet. J. 19, 458-462.

Mair T.S., C.R. Stokes and F.J. Bourne (1988): Distribution and ultrastructure of mast cells in the equine respiratory tract. Equine Vet. J. 20, 54-58

McGorum R.C., P.M. Dixon and R.E.W. Halliwell (1993): Responses of horses affected with chronic obstructive pulmonary disease to inhalation challenges with mould antigens. Equine Vet. J. 25, 261-267.

Mc Pherson E.A., G.H.K. Lawson, J.R. Murphy, J.M. Nicholson., R.G. Breeze and H.M. Pirie (1979): Chronic Obstructive Pulmonary Disease (COPD) in horses: Aetiological studies: Responses to intradermal and inhalation antigenic challenge. Equine Vet. J. 11, 159-166.

Moore B.R. (1996): Lower respiratory tract disease. Vet. Clin. N. Am.: Equine Pract. 12, 457-472.

Navarotto PI , M. Guarino and A. Santambrogio (1994). Evaluation of the environmntal dust and mycetes in a Throughbred stable Transactions of the ASAE 37, 229-233

Pickrell J. (1991): Hazards in confinement house - gases and dusts in confined animal houses for swine, poultry, horses and humans Vet. Hum. Toxicol. 33, 32-39

Robertson J. (1992): Dust and ammonia in pig buildings. Farm building progress 1 10, 19-24SAS (1988): SAS/STAT Users's guide. SAS Inst. Inc. , Cary, NC. USA.

Sibille Y. and H.Y. Reynolds (1990): Macrophages and polymorphonuclear neutrophils in lung defense and injury. Am. Rev. Respir. Dis. $141,471-501$.

Woods P.S.A., N.E. Robinson, M.C. Swanson, C.E. Reed, R.V. Broadstone and F.J. Derksen (1993): Airborne dust and aeroallergen concentration in a horse stable under two different management systems. Equine Vet. J. 25, 208-213.

Zeitler-Feicht M.H. (1993): Mindestanforderungen an die Beleuchtung und Stalluft in der Pferdehaltung unter Tierschutzgesichtspunkten. Tierärztl. Umschau 48, 311-317.

\section{Dr. Elisabetta Ferro}

Istituto di Patologia Speciale e Clinica Medica Veterinaria

Facoltà di Medicina Veterinaria

via Celoria 10

I-20133 Milano 